\title{
Control of annual reproductive cycle in the subtropical house sparrow (Passer domesticus): evidence for conservation of photoperiodic control mechanisms in birds Amit K Trivedi, Sangeeta Rani and Vinod Kumar*
}

Address: Department of Zoology, University of Lucknow, Lucknow 226007, India

Email: Amit K Trivedi - amit_9trivedi@yahoo.com; Sangeeta Rani - sangeetarani7@yahoo.com; Vinod Kumar* - drvkumar11@yahoo.com

* Corresponding author

Published: 22 August 2006

Frontiers in Zoology 2006, 3:12 doi:10.1186/1742-9994-3-12
Received: 12 May 2006

Accepted: 22 August 2006

This article is available from: http://www.frontiersinzoology.com/content/3/I//2

(c) 2006 Trivedi et al; licensee BioMed Central Ltd.

This is an Open Access article distributed under the terms of the Creative Commons Attribution License (http://creativecommons.org/licenses/by/2.0), which permits unrestricted use, distribution, and reproduction in any medium, provided the original work is properly cited.

\begin{abstract}
Background: In many birds, day length (=photoperiod) regulates reproductive cycle. The photoperiodic environment varies between different seasons and latitudes. As a consequence, species at different latitudes may have evolved separate photoperiodic strategies or modified them as per their adaptive need. We studied this using house sparrow as a model since it is found worldwide and is widely investigated. In particular, we examined whether photoperiodism in house sparrows (Passer domesticus) at $27^{\circ} \mathrm{N}, 81^{\circ} \mathrm{E}$ shared features with those exhibited by its conspecifics at high latitudes.

Results: Initial experiment described in the wild and captive conditions the gonad development and molt (only in captives) cycles over a 12-month period. Both male and female sparrows had similar seasonal cycles, linked with annual variations in day length; this suggested that seasonal reproduction in house sparrows was under the photoperiodic control. However, a slower testis and attenuated follicular growth among captives indicated that other (supplementary) factors are also involved in controlling the reproductive cycle. Next experiment examined if sparrows underwent seasonal variations in their response to stimulatory effects of long day lengths. When birds were transferred every month over a period of 1 year to 16 hours light:8 hours darkness (I6L:8D) for 17-26 weeks, there was indeed a time-of-year effect on the growth-regression cycle of gonads. The final experiment investigated response of house sparrows to a variety of light-dark (LD) cycles. In the first set, sparrows were exposed for 31 weeks to photoperiods that were close to what they receive in between the period from sunrise to sunset at this latitude: 9L: I5D (close to shortest day length in December), I2L: I2D (equinox, in March and September) I5L:9D (close to longest day length in June). They underwent testicular growth and regression and molt in $12 \mathrm{~L}$ and I5L photoperiods, but not in $9 \mathrm{~L}$ photoperiod. In the second set, sparrows were exposed for 17 weeks to photoperiods with light periods extending to different duration of the daily photosensitivity rhythm (e.g. 2L:22D, 6L:18D, 10L:14D, 14L:10D, 18L:6D and 22L:2D). Interestingly, a slow and small testicular response occurred under $2 \mathrm{~L}$ and $10 \mathrm{~L}$ photoperiods; $6 \mathrm{~L}: 18 \mathrm{D}$ was non-inductive. On the other hand, $14 \mathrm{~L}, 18 \mathrm{~L}$ and $22 \mathrm{~L}$ photoperiods produced testicular growth and subsequent regression response as is typical of a long day photostimulation.
\end{abstract}

Conclusion: Subtropical house sparrows exhibit photoperiodic responses similar to that is reported for its population living at high latitudes. This may suggest the conservation of the photoperiodic control mechanisms in birds evolved over a long period of time, as a physiological strategy in a temporally changing environment ensuring reproduction at the best suited time of the year. 


\section{Background}

Many birds exhibit seasonal cycles in several functions including body mass, plumage color, hormone levels, gonadal growth and development, beak pigmentation, song production, nest building, molt, parasitic load, immune system etc. [1-4]. Most of these functions center on the reproduction, which is timed to occur in the year when the surrounding environment, which itself is seasonal, is maximally favorable for the survival of the offspring [5]. Seasonal activities often appear linked with the changes in environmental photoperiod, although cues like changes in food supply and temperature can influence the timing of a seasonal event [1-7].

The role of day length (=photoperiod) in control of the initiation and termination of events associated with seasonal reproduction is shown in a number of species breeding both at high and low latitudes [for references see [1-9]]. Interestingly, tropical species experiencing relatively smaller amplitude of annual photoperiodic cycle also appear responding to sufficiently small changes in light hours, and they use this cue to time their breeding [3,6,9-11]. Day light interacts with the endogenous daily photosensitive rhythm and regulates growth and development of gonads. Experiments on long day breeding species have established that during spring and summer seasons when daylight exceeds $12 \mathrm{~h}$ per day, light later in the day ( $\sim 12 \mathrm{~h}$ after the beginning of the day) coincides with the photoinducible phase of the endogenous circadian ( irca = about; dies = day) rhythm; this causes induction of a photoperiodic response [12]. There is also evidence of the endogenous circannual ( $\operatorname{circa}=$ about; annum = day) rhythmicity regulating gonadal cycle in a few species $[9,13]$, although it is unclear yet whether the circannual rhythmicity is completely separate from the circadian rhythmicity. A circannual rhythm may comprise the sequences of mutually exclusive phases, as evidenced from a study on European starlings (Sturnus vulgaris) [14]. In starlings held on 12L:12D, circannual rhythms in plasma LH was abolished after castration suggesting that one of the phases of the circannual rhythmicity was dependent on circulating gonadal steroids [14].

The strength of the environmental zeitgeber (zeit = time, geber = giver; e.g. light-dark [LD] cycle) influences circadian and circannual clocks controlling periodic functions [8]. The photoperiodic environment which acts as zeitgeber for the endogenous clocks underlying seasonality in most bird species [8] varies with the latitudes and seasons. Therefore, a photoperiodic species may exhibit latitudeand season-dependent photoperiodic adaptations. A few studies in fact show this. Great tits (Parus major) living in Malaya $\left(3^{\circ} \mathrm{N}\right)$ have longer breeding season compared to the north European $\left(>45^{\circ} \mathrm{N}\right)$ and British $\left(>51^{\circ} \mathrm{N}\right)$ populations [15]. The duration of the postnuptial molt in white-crowned sparrows (Zonotrichia leucophrys gambelii) decreases by an average of 2.6 days per degree of increase in latitude ( 83 days at $35^{\circ} \mathrm{N}$ compared to 47 days at $49^{\circ} \mathrm{N}$; [16]). In a study at $48^{\circ} \mathrm{N}$, redpolls brought from $65^{\circ} \mathrm{N}$ exhibited seasonal response different from its conspecifics that were resident [17]. A study on deer mice (Peromyscus maniculatus, [18] suggests that the latitude of origin dictates photoperiodic regulation of the reproductive system. Differences in photoresponsiveness can occur even between populations from similar latitudes, as indicated by studies on blue tits (Parus caeruleus) $[19,20]$. It is likely that such latitudinal or populational differences are purely adaptational, and have not fundamentally changed the physiology of the species. A study of Moore et al. [21] found no difference in GnRH challenged plasma testosterone levels between mid-latitude breeder Puget Sound white-crowned sparrows (Zonotrichia leucophrys pugetensis) and high-latitude breeder Gambel's white-crowned sparrows (Zonotrichia leucophrys gambelii); interestingly, equatorial rufous-collared sparrow (Zonotrichia capensis) exhibited greater plasma testosterone levels than high latitude species.

The fact that both high- and low-latitude species possess sensitivity to even very small changes in photoperiods [19] illustrates that inhabiting different photoperiodic environments they necessarily represent adaptations. Studying photoperiodic adaptations in a bird species distributed widely covering different latitudes can therefore be much interesting. The prediction would be that populations living in the north would delay the onset of gonadal growth compared to their conspecifics from the south because of the difference in amplitude of annual photoperiodic cycle the two populations will be exposed to. This may be achieved by (i) the change in the photoperiodic threshold for gonadal growth, and (ii) the adjustment to local cues like temperature and food availability. Silverin et al. [22] tested this in great tits by comparing responses of birds under same lighting conditions from three different latitudes $\left(45^{\circ}, 57^{\circ}\right.$ and $\left.70^{\circ} \mathrm{N}\right)$. Birds breeding in the north had higher photoperiodic threshold than those breeding in the south. The results showed greater variability in breeding behavior between the populations of great tits from three different latitudes, and led to conclusion that selection pressure favored photoperiodic cues over nonphotoperiodic cues [22]. A study on blue tits supported this by showing that a long photoperiod can override non-photoperiodic factors in timing of the reproduction [23]. Because all three great tit populations employed in the study were still from temperate latitudes $\left(>40^{\circ} \mathrm{N}\right)$, a study of the photoperiodic adaptations in a species from subtropics/tropics could be more interesting.

House sparrow (Passer domesticus) is found all over the world and is one of most widely investigated bird species. 


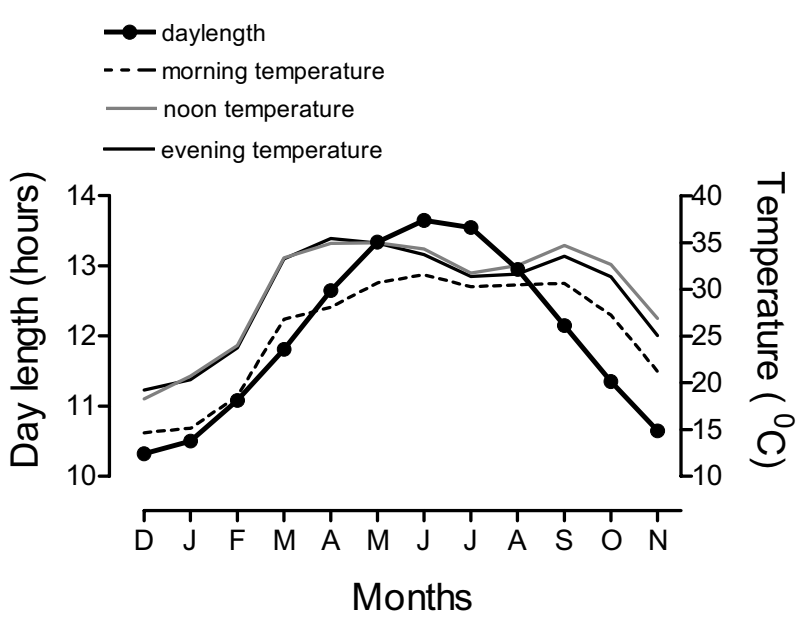

Figure I

Variations in lighting and temperature conditions at $27^{\circ} \mathrm{N}$, $81^{\circ} \mathrm{E}$ over the 12 month period, from December 2001 to November 2002 recorded in middle of every month. Data on day length are plotted for $15^{\text {th }}$ of each month. Data on temperature were recorded in middle of the aviary at $0800 \mathrm{~h}$, $\mathrm{I} 200 \mathrm{~h}$ and $\mathrm{I} 700 \mathrm{~h}$.

Studies on high latitude house sparrows have established that (i) sparrows are annually breeding species exhibiting seasonal variations in gonadal size and reproductive hormones including levels of GnRH (gonadotropins releasing hormone) and GnIH (gonadotropin inhibitory hormone) [24-26], (ii) day length controls the timing of the initiation and termination of the annual gonadal cycle [27-30], and (iii) photoperiod-induced gonadal function is mediated by the circadian rhythms [31-33]. Further, there could be differences in the breeding seasons among house sparrow populations from relatively similar latitudes. Murton and Westwood [34] in their study on British sparrows found Surrey $\left(51^{\circ} \mathrm{N}\right)$ sparrows in more advanced stage of their vernal recrudescence than Cambridgeshire $\left(52^{\circ} \mathrm{N}\right)$ sparrows at the same time of the year. The difference in the timing of breeding of sparrows was probably due to the differences in food availability as a consequence of ambient temperatures at two places, and not due to photoperiodic conditions which were almost the same. Experimentally, it has been shown that the duration and timing of food availability influences the rate of photoperiodic induction of testicular growth in house sparrows [35]. Further, a study on four populations of house sparrows [36] spread over a latitudinal range of $18^{\circ}$ (between $34^{\circ} \mathrm{N}$ and $52^{\circ} \mathrm{N}$ ) concluded that the durations of spermatogenesis and photorefractoriness varied with the latitude. As latitudes increased, the duration of spermatogenesis shortened and the duration of photorefractoriness lengthened.
Hence, with large data sets from the populations around the world, house sparrow presents an ideal opportunity to investigate if the photoperiodic strategy involved in regulation of avian seasonal cycles is conserved. That is, whether the fundamental property of photoperiodic cue response system is retained by house sparrow although its populations inhabiting different latitudes could generate appropriate adjustments to local conditions such as weather, food availability, temperature, etc. To test this, we carried out the present study on house sparrow at $27^{\circ} \mathrm{N}, 81^{\circ} \mathrm{E}$, since no such detailed study has ever been done at these latitudes. The general prediction was that house sparrows at this latitude $\left(27^{\circ} \mathrm{N}\right)$ will show photoperiodic responses more like to those at $34^{\circ} \mathrm{N}$, reported above [36]; i.e. they will have longer breeding season as indicated by the growth and regression of gonads under experimental conditions. In different experiments, we have (i) described the annual gonad development cycle in the wild and captive conditions, (ii) examined the changes in responsiveness to a long day length (16 hours light:8 hours darkness; 16L:8D) over different months of the year, and (iii) investigated the induction and regression of gonadal responses under different photoperiods.

\section{Results}

Figure 1 shows annual variations in the length of daily light period from sunrise to sunset and temperature in the middle of the aviary measured three times in the day: at $0800 \mathrm{~h}, 1200 \mathrm{~h}$ and $1700 \mathrm{~h}$. At $27^{\circ} \mathrm{N}, 81^{\circ} \mathrm{E}$, the range of annual variation in day length was about 3.5 hours. Daily temperature cycle also exhibited a seasonal pattern.

\section{Series A: Gonad development cycle under natural day lengths: effect of captivity \\ Experiment I}

Figure 2 presents data on testis volume and follicle diameter of birds captured each month from the wild. Testes underwent significant annual growth-regression cycle $\left(\mathrm{F}_{11,102}=24.15, \mathrm{P}<0.0001,1\right.$-way ANOVA; Fig. 2a $)$. In December, all birds had regressed testes, but a month later (January) 5 of 10 birds had slightly initiated testicular growth $\left(\mathrm{TV}=3.20 \pm 0.80 \mathrm{~mm}^{3}\right)$ and 2 months later (February) 9 of 10 birds had moderately grown testes (TV = $22.0 \pm 8.00 \mathrm{~mm}^{3}$ ). When captured in March, few birds in the group still had unstimulated testes, which reflected asynchronous testicular growth within the population. All birds captured in April, however, had fully grown testes $\left(\mathrm{TV}=98.4 \pm 13.00 \mathrm{~mm}^{3}\right)$. Testicular regression had begun by May; half of birds examined in this month had smaller testes (small to moderate response). June birds had variable testicular regression, but July birds had fully regressed testes. In between August and October, half of the sparrows captured had regressed testes and the remaining half had slightly larger testes (TV $=<9.82 \mathrm{~mm}^{3}$ ). In November, the number of birds with regressed testes further declined. 
Gonad (Experiment 1, 2)
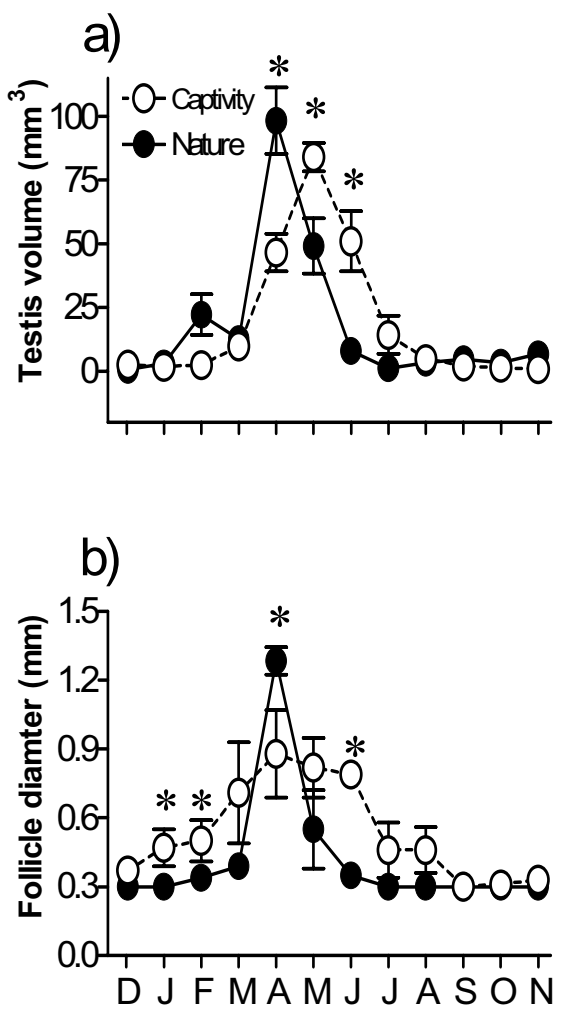

Molt (Experiment 2)
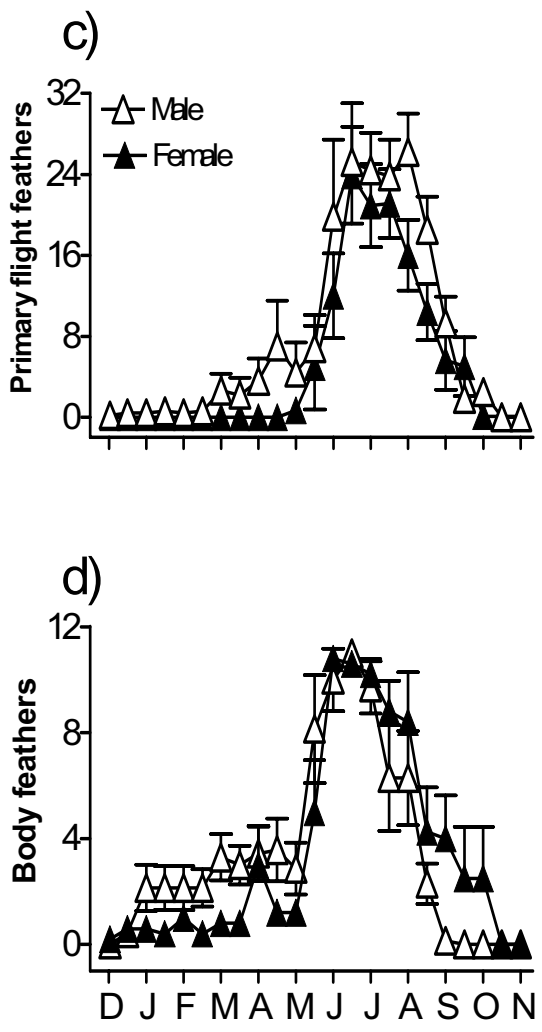

Months

Figure 2

Mean $( \pm \mathrm{SE})$ testis volume (a), follicle diameter (b), and molt scores of primary flight (c) and body feathers (d) of male and female house sparrows procured every month from the wild or kept in the out door aviary from December through November. In captives, peak testicular growth was delayed by 4 weeks (a), and follicular growth was attenuated (b). Also, the shape of curve reflecting ovarian growth and regression was difference between wild and captive sparrows (b). Asterisks show significant difference $(P<0.05)$ in the response between the two conditions.

Ovary underwent similar significant annual growthregression cycle $\left(\mathrm{F}_{11,88}=43.04, \mathrm{P}<0.0001,1\right.$-way ANOVA; Fig. 2b). All sparrows examined from December to February had fully regressed (indistinct) follicles. In March, 3 of 10 sparrows had slightly enlarged follicle, but in April, all sparrows had fully enlarged follicle (FD = 1.29 $\pm 0.06 \mathrm{~mm}$ ). By May, majority of sparrows had regressed their ovary $(\mathrm{FD}=0.55 \pm 0.17 \mathrm{~mm})$; ovary remained regressed in subsequent months of June to November (Fig. 2b).

\section{Experiment 2}

Sparrows held in captivity underwent similar significant growth-regression cycle of gonads (testis: $\mathrm{F}_{11,44}=32.69, \mathrm{P}$ $<0.0001$; ovary: $\mathrm{F}_{11,66}=5.692, \mathrm{P}<0.0001$, 1-way RM
ANOVA; cf. Figs. 2a and 2b). Testes were stimulated in March, and grew to full size by May. Regression began by June, and testes were fully regressed by August (Fig. 2a). Similarly, follicular growth was initiated in March, and enlarged follicles were found from April to June. Thereafter, regression began and by September all birds had fully regressed ovary with indistinct follicles.

Molt of wing primaries and body feathers of both sexes progressed with gonadal regression (cf. Figs. 2a-d). When compared over 12 months, molt scores of wing primaries and body feathers showed significant variation (male: $\mathrm{F}_{22,88}=14.16, \mathrm{P}<0.0001$ [primaries], $\mathrm{F}_{22,88}=10.87, \mathrm{P}<$ 0.0001 [body]; female: $\mathrm{F}_{22,132}=18.85, \mathrm{P}<0.0001$ [primaries], $\mathrm{F}_{22,132}=12.47, \mathrm{P}<0.0001$ [body]); maximum scores 
Male

a)

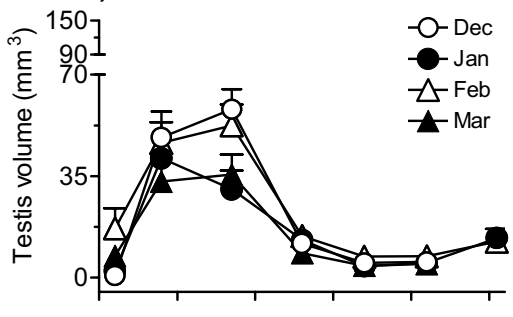

b)

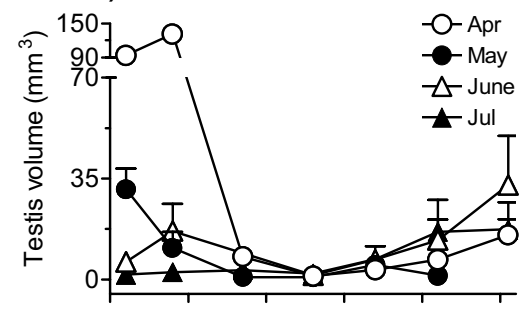

c)

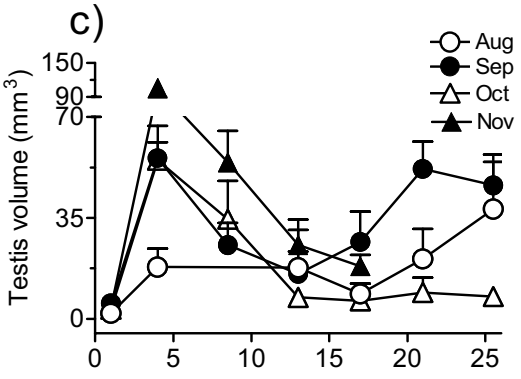

Female

d)

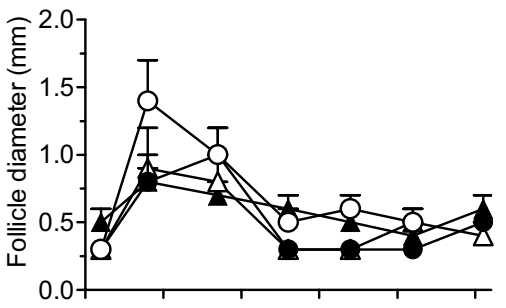

e)

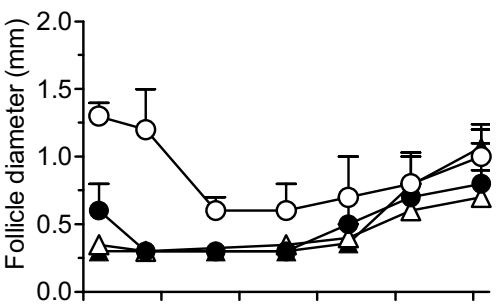

f)

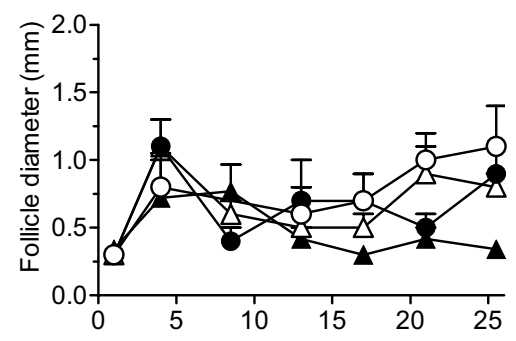

Weeks

Figure 3

Mean $( \pm S E)$ testis volume $(a-c)$ and follicle diameter $(d-f)$ of house sparrows $(n=5-9$ each) procured from the wild every month, and transferred to 16 hours light :8 hours darkness (I6L:8D) from December 2002 to November 2003 for a period of 17 to 26 weeks. Data are plotted in groups of 4 months for the sake of clarity. There was a time-of-year effect on the gonadal response to $16 \mathrm{~L}: 8 \mathrm{D}$, which suggested that physiological mechanisms underlying reproductive cycle in house sparrows underwent seasonal changes.

were found in July and August and minimum in November. Individuals differed in the timing of the onset of molt, but all members of the group completed molt by October or November.

A comparison of gonadal growth-regression cycles between two experiments by 2-way ANOVA (factor 1: condition - wild vs. captive; factor 2, season of the growth and regression) revealed a significant effect of the condition $\left(\mathrm{F}_{11,155}=11.88, \mathrm{P}=0.0007\right)$ in female but not in male sparrows $\left(\mathrm{F}_{11,151}=0.0250, \mathrm{P}=0.8745\right)$. However, the sea- sons (males: $\mathrm{F}_{11,151}=30.60, \mathrm{P}<0.0001$; females: $\mathrm{F}_{11,155}=$ $20.49, \mathrm{P}<0.0001)$ and the interaction between the condition and season (males: $\mathrm{F}_{11,151}=6.727, \mathrm{P}<0.0001$; females: $F_{11,155}=4.427, P<0.0001$ ) had significant effects in both sexes.

\section{Series B: Season-dependent variation in sensitivity of the photoperiodic response system}

Figure 3 shows results. Sparrows underwent significant change in gonadal size (growth or regression depending on the time of the year) when exposed for 17 to 26 weeks 

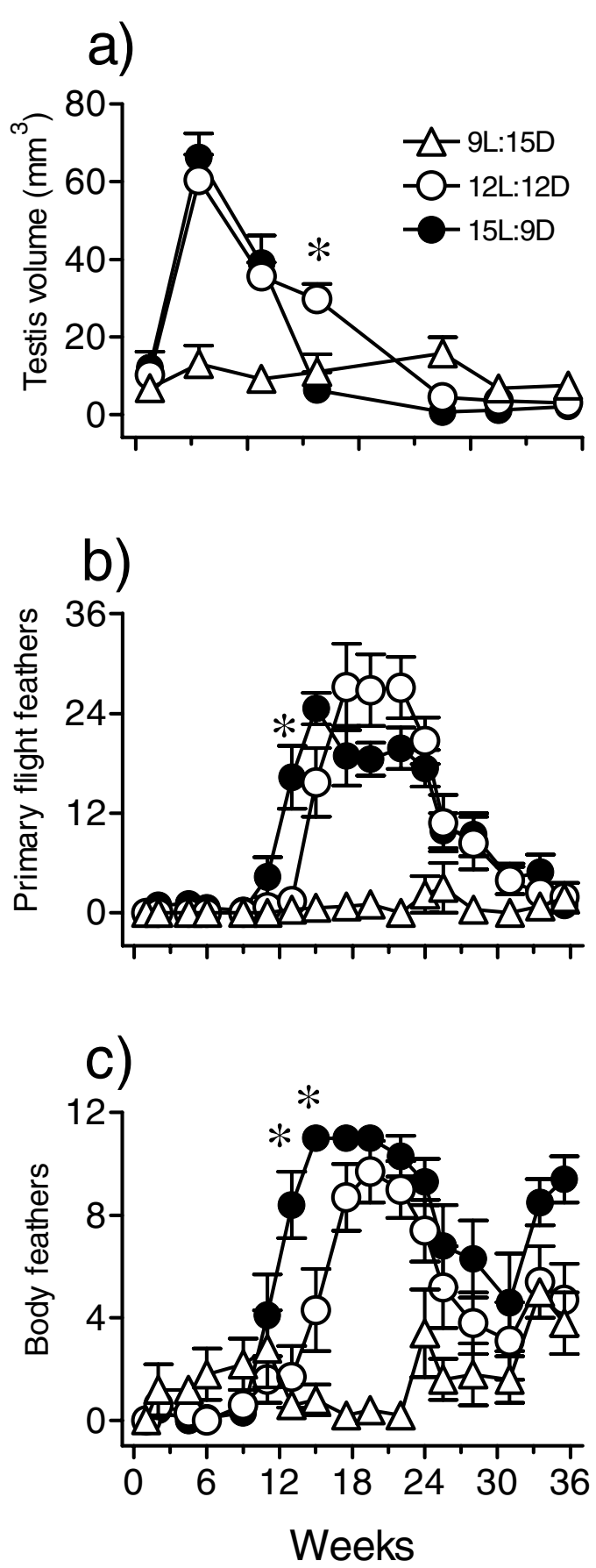

\section{Figure 4}

Mean ( \pm SE; $n=7-8$ ) testis volume (a) and molt score of primary flight (b) and body feathers (c) of male house sparrows exposed to a short day length (9L:I5D), equinox day length (I2L:I2D), and long day length (I5L:9D) for a period of 36 weeks. Whereas 9L did not induce growth-regression of gonads or molt, I $2 \mathrm{~L}$ and $\mathrm{I} 5 \mathrm{~L}$ did. Also, photoperiodic induction and hence subsequent regression and molt were earlier in I5L than in I2L. Asterisks show significant difference between groups on the day of observation $(P<0.05)$ to long day lengths (16L:8D) each month over a 12 month period (December: $\mathrm{F}_{5,35}=37.83, \mathrm{P}<0.0001$; January: $\mathrm{F}_{6,42}=21.60, \mathrm{P}<0.0001$; February: $\mathrm{F}_{6,24}=18.45, \mathrm{P}<$ 0.0001; March: $\mathrm{F}_{5,40}=7.98, \mathrm{P}<0.0001$, April: $\mathrm{F}_{6,48}=$ 48.25, $\mathrm{P}<0.0001$; May: $\mathrm{F}_{5,20}=11.40, \mathrm{P}<0.0001$; June: $\mathrm{F}_{5,20}=2.795, \mathrm{P}<0.05 ;$ July: $\mathrm{F}_{6,24}=2.870, \mathrm{P}=0.0298$; August: $\mathrm{F}_{5,30}=3.053, \mathrm{P}=0.0241$; September: $\mathrm{F}_{6,36}=6.494$, $\mathrm{P}<0.0001$; October: $\mathrm{F}_{6,24}=12.07, \mathrm{P}<0.0001$; November: $\mathrm{F}_{4,20}=32.21, \mathrm{P}<0.0001 ;$ 1-way RM ANOVA). During December through March, testes grew in size in the first 4 - 9 weeks of 16L:8D (Fig. 3a), and then regressed. In April sparrows when they already had recrudesced testes (TV = $93.77 \pm 12.10 \mathrm{~mm}^{3}$ ), $16 \mathrm{~L}$ first induced further growth (TV $=131.7 \pm 14.0 \mathrm{~mm}^{3}, \mathrm{P}<0.001$, Newman-Keuls test $)$ and then an abrupt regression (Fig. 3b). 16L did not prevent testicular regression in May birds; they became fully regressed by the end of 9 weeks of exposure (Fig. 3b). June and July sparrows were partially recrudesced in 17 weeks (Fig. 3b). August birds showed a small initiation of testis growth $\left(\mathrm{F}_{5,30}=3.053, \mathrm{P}=0.0241\right.$; 1-way RM ANOVA $)$ but in birds of September through November, a full testicular growth $(\mathrm{P}<0.0001)$ occurred within 4 weeks; this indicated that by this time photorefractoriness was completely broken (Fig. 3c).

Similar significant changes in follicular diameter occurred in all months of the year, except in June (Figs. 3d-f). (December: $\mathrm{F}_{5,35}=6.731, \mathrm{P}=0.0002$; January: $\mathrm{F}_{6,30}=$ 6.185, $\mathrm{P}<0.0001$; February: $\mathrm{F}_{6,18}=6.087, \mathrm{P}=0.0131$; March: $\mathrm{F}_{6,48}=2.631, \mathrm{P}=0.0275$, April: $\mathrm{F}_{6,36}=4.703, \mathrm{P}=$ 0.0013; May: $\mathrm{F}_{6,30}=2.989, \mathrm{P}=0.0207$; June: $\mathrm{F}_{5,15}=1.190$, $\mathrm{P}=0.3601$; July: $\mathrm{F}_{6,36}=8.267, \mathrm{P}<0.0001$; August: $\mathrm{F}_{5,25}=$ 3.178, $\mathrm{P}=0.0235$; September: $\mathrm{F}_{6,36}=5.809, \mathrm{P}=0.0003$; October: $\mathrm{F}_{6,48}=4.691, \mathrm{P}=0.0008$; November: $\mathrm{F}_{6,24}=$ 2.642, $\mathrm{P}<0.05$; 1-way RM ANOVA). Ovarian growth occurred within 4 to 9 weeks of 16L:8D in birds of December through March (Fig. 3d). In April birds with developed ovary, follicles regressed in 9 weeks of 16L (Fig. 3e). Birds subjected to $16 \mathrm{~L}$ in May through July did not show photoinduction, except a small initiation at the end of the experiment in July birds (Fig. 3e). 16L caused a significant $(\mathrm{P}<0.05$, Newman Keuls test) increase in follicular diameter within 4 weeks in the month of August through October, which indicated regaining of the photoresponsiveness (Fig. 3f). November group however had variable response; 2 of 5 individuals did not show follicular growth at least until 22 weeks of exposure (Fig. 3f).

\section{Series C: Response to varying light-dark (LD) cycles Experiment I}

Figure 4 shows results. Testes did not undergo growthregression cycle in birds exposed to 9L:15D $\left(\mathrm{F}_{6,56}=\right.$ $0.9426, \mathrm{P}=0.4723$; 1 -way RM ANOVA). But, a full recrudescence-regression cycle occurred in those exposed to 12L:12D and 15L:9D (12L:12D - $\mathrm{F}_{6,63}=38.56, \mathrm{P}<$ 


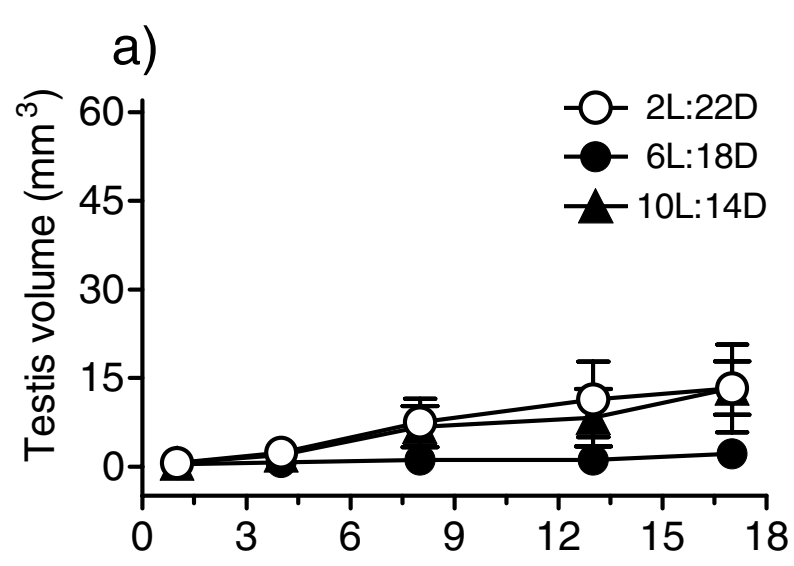

b)

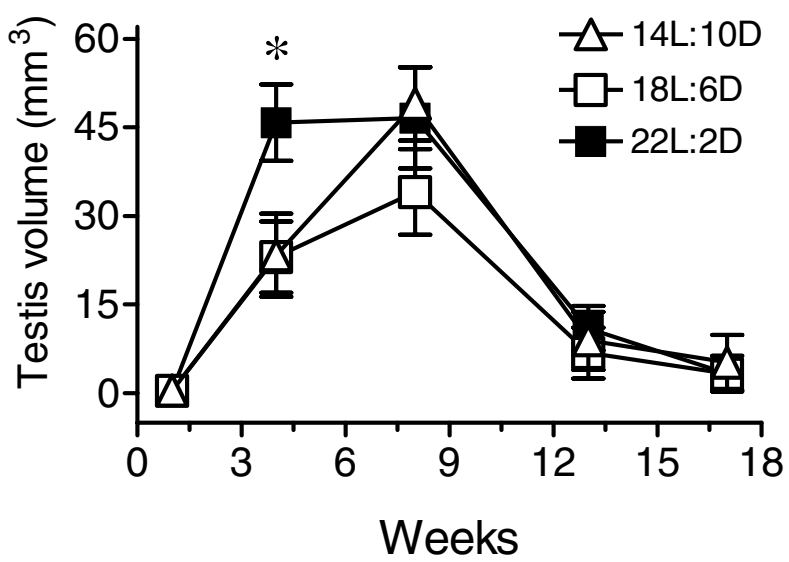

Figure 5

Mean $( \pm S E)$ testis volume of male house sparrows $(n=9-10)$ subjected for 17 weeks to photoperiods with increasing lengths of daily light periods. a: 2L:22D, 6L:I8D and IOL:I4D. A slow and small testicular response occurred in $2 \mathrm{~L}$ and $10 \mathrm{~L}$, but not in $6 \mathrm{~L}$ photoperiod, except that 2 of 7 birds in this group showed small initiation at the end of the experiment. b: I4L:I0D, 18L:6D and 22L:2D. A faster induction of testicular growth occurred in 22L, but regression was almost the same in all three photoperiods. Asterisk shows significant difference between $22 \mathrm{~L}$ and $18 \mathrm{~L}$ or I4L groups.

0.0001; 15L:9D - $\mathrm{F}_{6,56}=35.31, \mathrm{P}<0.0001$; 1-way $\mathrm{RM}$ ANOVA). The timing and magnitude of peak testis response were similar in $12 \mathrm{~L}$ and $15 \mathrm{~L}$ photoperiods. However, testes regressed relatively slowly under 12L:12D (Fig. 4 a); fully regressed testes were found by week 22 of $12 \mathrm{~L}$ compared to week 13 of 15L.

Data on molt scores of birds under 9L:15D revealed the absence of molt in wing primaries and a partial and slow molt of body feathers (only body feather molt scores were distinct by the end of 24 weeks) (Fig. 4b,c). On the other hand, birds had undergone significant molt under $12 \mathrm{~L}$ and 15L photoperiods (12L:12D: body $-\mathrm{F}_{14,135}=20.82, \mathrm{P}$ $<0.0001$; wing primaries $-\mathrm{F}_{14,135}=12.11, \mathrm{P}<0.0001$; 15L:9D: body $-\mathrm{F}_{14,120}=14.85, \mathrm{P}<0.0001$; wing primaries $-\mathrm{F}_{14,120}=24.05, \mathrm{P}<0.0001 ; 1$-way RM ANOVA). Consistent with data on testes, the onset of molt of wing primaries and body feathers under 15L was significantly earlier than under 12L ( $\mathrm{P}<0.05$; Student's t-test) although molt completed almost at the same time in both the groups (cf. Figs. 4b,c). A comparison by 2 -way ANOVA also indicated significant difference between $12 \mathrm{~L}$ and $15 \mathrm{~L}$ groups in the molt of body feathers $\left(\mathrm{F}_{1,255}=32.38, \mathrm{P}<0.0001\right)$ but not of wing primaries $\left(\mathrm{F}_{1,255}=0.4337, \mathrm{P}=0.5108\right)$.

\section{Experiment 2}

Figure 5 shows results. A significant testicular growthregression cycle occurred during 17 weeks of $14 \mathrm{~L}, 18 \mathrm{~L}$ and $22 \mathrm{~L}$ photoperiods $\left(14 \mathrm{~L}: 10 \mathrm{D}-\mathrm{F}_{4,28}=13.52, \mathrm{P}<0.0001\right.$; $18 \mathrm{~L}: 6 \mathrm{D}-\mathrm{F}_{4,24}=10.02, \mathrm{P}<0.0001 ; 22 \mathrm{~L}: 2 \mathrm{D}-\mathrm{F}_{4,24}=22.45$, $\mathrm{P}<0.0001 ;$ 1-way RM ANOVA). The magnitude of response among $14 \mathrm{~L}, 18 \mathrm{~L}$ and $22 \mathrm{~L}$ groups was similar, but the rate of testicular growth was significantly faster $(\mathrm{P}<$ 0.05 ; 1 -way ANOVA) in the 22L group. The timing of testis regression was interestingly the same in all of them (Fig. 5b). Surprisingly, 1-way RM ANOVA of the data from short photoperiods showed significant increase in testis size in $2 \mathrm{~L}$ and $10 \mathrm{~L}$ photoperiods, but not in the $6 \mathrm{~L}$ photoperiod (2L:22D $-\mathrm{F}_{4,24}=2.886, \mathrm{P}<0.05 ; 6 \mathrm{~L}: 18 \mathrm{D}-\mathrm{F}_{4,24}$ $\left.=2.012, \mathrm{P}=0.1249 ; 10 \mathrm{~L}: 14 \mathrm{D}-\mathrm{F}_{4,28}=3.206, \mathrm{P}=0.0275\right)$. The response to $2 \mathrm{~L}: 22 \mathrm{D}$ and 10L:14D was nonetheless significantly slower $(\mathrm{P}<0.05$; F-test $)$, smaller and variable (cf. Figs. 5a,b). At the end of the experiment, the response among $2 \mathrm{~L}$ birds varied from full response $(n=2)$ to initiation of response $(n=3)$ to no response $(n=2)$. Similarly, among 10L birds it varied from full response $(n=1)$ to moderate response $(n=1)$ to small response $(n=2)$ to initiation of response $(n=4)$. In nonstimulatory 6L:18D, 5 of 7 birds never responded, and of the remaining 2 birds, one had small and the other had slightly initiated response.

\section{Discussion}

There appears a close correspondence between the gonad development cycle of house sparrow and annual variations in day length (cf. Figs. 1 and 2). Increasing photoperiods ( $\geq 12 \mathrm{~h}$ per day) of spring months (March, April) triggered the gonadal growth, but then gonads regressed during summer months (June or July) when day lengths were still much longer than of spring months. Similar to that described in the annual reproductive cycles of many species including temperate house sparrows $[8,27,37]$, this post-reproductive refractory period suggests that the physiological mechanisms controlling reproductive cycle 
in the subtropical house sparrows undergo dramatic changes in their response to day length. Interestingly, a study of Misra et al. [38] on blackheaded bunting (Emberiza melanocephala) showed the evidence of seasonal changes in photoresponsiveness even when birds were maintained on a non-stimulatory short photoperiod, which is widely used to ensure photosensitivity in a photoperiodic species. In buntings maintained since February on $8 \mathrm{~L}: 16 \mathrm{D}$ and subjected to $16 \mathrm{~L}: 8 \mathrm{D}$ from March to August, the magnitude of testicular response declined as short days progressed until July when the response was restored.

Figure 2 shows that the gonad development and molt cycles of house sparrow at $27^{\circ} \mathrm{N}, 81^{\circ} \mathrm{E}$ closely compare with those of its population living at high latitudes. A study on sparrows at $52^{\circ} \mathrm{N}$ reported that testes grew in size steadily until May, remained large in June and were fully regressed by late August [27]. In this study, one-fifth of sparrows began molt of their primary flight feathers by late July, all were molting a month later, and the molt was complete by early November. Compared to this, our sparrows had largest gonads in May and were fully regressed in July. Molt began in June, progressed steadily and was almost complete by late September. Thus, sparrows at $27^{\circ} \mathrm{N}$ appeared exhibiting a photoperiodic strategy in regulation of their reproductive cycle, similar to their high latitude conspecifics (Figs. 2a,b). This is interesting since a previous study on Indian house sparrows at $22^{\circ} \mathrm{N}, 88^{\circ} \mathrm{E}$ reported a longer breeding season lasting for 10 months [39]. The difference in reproductive cycle of these two Indian studies could be attributed to the difference in the food availability as a consequence of the differences in changes in temperature over seasons at these two latitudes, similar to that reported for high latitude birds $[34,35,40,41]$. In Threadgold's study also, sparrows of $34^{\circ} \mathrm{N}$ had longer breeding season than those of $52^{\circ} \mathrm{N}$ [36]. Whatever explanation is offered, these findings tend to suggest that actual breeding strategy in birds is modified by local conditions of the given latitude.

A comparison of gonad development cycle between the wild and captive sparrows revealed that in captives (i) the attainment of peak testicular growth was delayed, (ii) the amplitude of follicular growth was attenuated, and (iii) overall duration of the gonadal growth phase was longer (Figs. 2a,b). These differences could have occurred due to one or all of the following reasons. (1) The two conditions were different in terms food availability. Whereas wild sparrows had free access to all kinds of food in its environment, captive sparrows had fixed diet of seeds of Setaria italica and Oriza sativa. Several reports suggest the effects of food availability on the gonadal development [40,4042]. (2) Absence of supplementary factors including opportunity of pair-formation to captives modified their gonad development cycle [1,43]. (3) Confinement within the aviary ( size $=3.0 \times 2.5 \times 2.5 \mathrm{~m}^{3}$ ) may have been stressful; this in turn affected the activity of hypothalamo-hypophyseal-gonadal axis, and hence the timing and magnitude of gonadal growth and development in captives $[44,45]$.

Results of the series B experiments further support the idea of seasonality in photoresponsiveness of house sparrows (Fig. 3). A 16L photoperiod did not prevent the collapse of large gonads in May birds or re-initiate recrudescence of regressed gonads in June and July birds, but caused recrudescence in September sparrows. This suggested that there was a seasonality in loss and gain of photoresponsiveness in sparrows. A comparable situation exists in several photoperiodic species including temperate zone grey partridge [Perdix perdix, [46]] and subtropical Indian weaver bird (Ploceus philippinus [47]) and brahminy myna (Sturnus pagodarum [48]). A study of Dawson [27] on house sparrows at $52^{\circ} \mathrm{N}$, nevertheless, provided slightly different results. In this study, sparrows shifted to 18L:6D in June did not regress their testes at least for the next 25 days; in fact, by mid-July testes under $18 \mathrm{~L}$ were significantly larger than those in natural day length at this time. The difference between our results and those of Dawson [27] could be due to difference in the amplitude of photoperiodic cycle which sparrows experienced at these two latitudes as well as due to local conditions such as temperature and food availability. It is known that ambient temperature significantly affects the photoperiodic induction of gonadal development and regression in birds $[49,50]$.

Data presented in figure $4 \mathrm{a}$ are consistent with the idea that longer the photoperiod, faster is the rate of gonadal growth and subsequent regression; hence, gonadal growth phase becomes narrower [38,51-53]. In the present study, the rate of photoperiodic induction and subsequent regression was faster in $15 \mathrm{~L}$ than in $12 \mathrm{~L}$ photoperiod (cf. Fig. 4a). Although the timings of the peak testicular response were not different between $12 \mathrm{~L}$ and $15 \mathrm{~L}$ groups (Fig. 4a), probably because a 4 -week interval of first observation was long enough to allow full testicular growth under both the photoperiods, the timing of the onset of testicular regression and molt clearly showed a faster photoinduction under 15L:9D (Fig. 4). Testes regressed (cf. data on week 13, Fig. 4a) and molt began earlier in 15L than in $12 \mathrm{~L}$ photoperiods (Fig. $4 \mathrm{~b}, \mathrm{c}$ ). Thus, as one would expect, molt followed the testicular regression: faster was the testicular regression, earlier was the onset of the molt (cf. Fig. $4 \mathrm{a}-\mathrm{c}$ ). A similar molt pattern has been reported in house sparrows of $52^{\circ} \mathrm{N}$ subjected to stimulatory photoperiods [27]. Photoperiodic control of molt is also reported in the European starling [54]. A close relationship between the gonadal regression and post-nuptial 
molt is known in several species [55]. The present results are also comparable to those reported on house sparrows at $52^{\circ} \mathrm{N}$ exposed to $18 \mathrm{~L}, 16 \mathrm{~L}$ and $13 \mathrm{~L}$ photoperiods [28]. In this study, as compared to that in $16 \mathrm{~L}$ and $18 \mathrm{~L}$, peak testis growth in 13L was delayed by 3 weeks. Similarly, testes regressed by $9,12,18$ weeks in $18 \mathrm{~L}, 16 \mathrm{~L}$ and $13 \mathrm{~L}$ groups, respectively [28]. Figure 5, however, shows that in sparrows exposed to $22 \mathrm{~L}, 18 \mathrm{~L}$ and $14 \mathrm{~L}$, testes recrudesced faster in the 22L photoperiod, as one would expect, but the subsequent regression was not different between the three photoperiods. It appears that the duration of testicular growth phase under stimulatory photoperiods is not altered when daily light period far exceeds the photoperiodic threshold (cf. Fig. 4a, 5). In other words, the extension of the light period into the photoinducible phase of the circadian rhythmicity underlying photoperiodism longer than $\sim 2$ h each day does not change the gonadal growth phase in house sparrows. This may be logical given the fact that sparrows at $27^{\circ} \mathrm{N}$ experience a maximum of about $14 \mathrm{~h}$ light per day (sunrise to sunset, Fig. $1)$, and hence the photoinducible phase of circadian rhythmicity in this species [56] is daily exposed to only slight greater than $2 \mathrm{~h}$ light period. A study of Rani and Kumar [57] on redheaded bunting (Emberiza bruniceps) provided the evidence that illumination of photoinducible phase beyond a critical duration did not enhance the testicular response.

At this latitude $\left(27^{\circ} \mathrm{N}, 81^{\circ} \mathrm{E}\right)$, house sparrows closely share habitat with weaver birds. Although there is a difference of about 4 weeks in peak testicular development between the two species (our unpublished data), both of them initiate their gonad development cycle with increasing day lengths of spring. Hence, they are expected to share similar photoperiodic mechanisms, although sparrow may have slightly lower photoperiodic threshold. Indeed, Indian weaver bird at $25^{\circ} \mathrm{N}$ is reported exhibiting testicular response to $9 \mathrm{~L}, 12 \mathrm{~L}$ and $15 \mathrm{~L}$ photoperiods $[47,58,59]$ similar to that is shown by sparrows in the current study (Fig. 4).

On exposure to short photoperiods ( $\leq 10 \mathrm{~h}$ per day), a long day breeder usually will not show gonadal recrudescence, which is indicative of the importance of photoperiodic cues over endogenous seasonal rhythm in the control of reproductive cycle of a species. However, if a long day breeder exhibits gonadal recrudescence under such short photoperiods, its response may be considered as a consequence of the seasonal rhythm rather than to the photoperiod. Results of the experiment 2 of series III (Fig. 5a) should be viewed against this background. Sparrows exhibited a testicular response, albeit slow and small, to 2L:22D and 10L:14D; however, no response to $6 \mathrm{~L}: 18 \mathrm{D}$ (cf. Fig. 5a). An earlier study has also reported testicular recrudescence under $1 \mathrm{~L}: 23 \mathrm{D}$ temperate house sparrows
[36]. In the current study, the small induction under $2 \mathrm{~L}$ and 10L photoperiods could be occurring due to different reasons. A $10 \mathrm{~h}$ square-wave of light at bright intensity in 10L:14D regime could be compared to a lighting situation in the natural environment closer to when sparrows would initiate testicular recrudescence. Therefore, sparrows continuously exposed to $10 \mathrm{~h}$ light per day exhibited small initiation of response. This is supported by the result under 6L:18D in which no significant enlargement of testes occurred. Several studies have shown spontaneous full growth and regression cycle of gonads under $12 \mathrm{~h}$ photoperiods [7]. On the other hand, we interpret small response under $2 \mathrm{~L}: 22 \mathrm{D}$ as the consequence of the annual rhythm of the growth-regression-regrowth of testes rather than of the photoperiodic condition. It is possible that a short photoperiod like $2 \mathrm{~L}: 22 \mathrm{D}$ is unable to sustain the entrainment of the endogenous clocks underlying seasonality in house sparrows. The photoperiodic entrainment of the circadian rhythmicity, which can be different under different zeitgeber conditions, sets the timing of the photoinductible phase [60], and the interaction of the latter with the light regulates gonad development cycle in photoperiodic birds [12,31-33].

In general, the timing and amplitude of the photoperiodic response differed between male and female sparrows (cf. Figs. 2a,b). Long days induced full testicular growth but only partial ovarian growth. It appears that increasing photoperiods induce initial slow growth phase and not the final fast or exponential growth phase of ovary, which is influenced by supplementary factors $[1,43]$; full reproductive competence in females is often determined by the stimuli from mate, nest site and food availability [8,6163]. Such a difference in photoperiodic regulation of seasonal cycles between sexes probably reflects an adaptive strategy since it restricts ovulation, and hence fertilization, until the time when the chances are favorable for the survival of the offspring.

\section{Conclusion}

House sparrows at $27^{\circ} \mathrm{N}, 81^{\circ} \mathrm{E}$ show photoperiodic responses similar to those of its populations living at high latitudes, e.g. $52^{\circ} \mathrm{N}$. This means that at relatively low-latitudes, house sparrow continues using photoperiodic cues from the environment to regulate their reproductive cycles. Studies on house sparrow show conservation of photoperiodic control mechanisms evolved over a long period of time, as an adaptive strategy in the temporal environment that ensures reproduction at the most suited time of the year. Differences in photoperiodic responses among populations of the same species inhabiting different latitudes could suggest specific adaptations required by a species at the given latitude. 


\section{Methods}

Three series of experiments were performed on adult house sparrow (Passer domesticus) captured from the wild and kept in an outdoor aviary until the beginning of the experiment. Our outdoor aviaries are situated on the roof of the first floor (at the height of about $3 \mathrm{~m}$ from the ground) and receive unrestricted natural lighting and temperature conditions.

\section{Series A: Gonad development cycle under natural day lengths: effect of captivity}

We studied changes in the sizes of testis and ovarian follicle over a 12-month period to describe gonad development cycle in the wild and captive house sparrows in relation to annual variations in day length. If factors other than day length also contributed to mechanisms controlling growth and regression of gonads, then there would be a difference in the magnitude of growth and/or temporal phasing of gonadal cycle between wild and captive sparrows. Two experiments were performed.

\section{Experiment I}

Beginning from December 2001 over the next 12 months, the size of testis and ovarian follicle were measured in a group of male ( $n=6-10$ each) and female $(n=4-10$ each) sparrows captured in the middle of every month from the wild.

\section{Experiment 2}

In December 2002, a group of male and female sparrows $(\mathrm{n}=8$ each) were kept in the outdoor aviary (size $=3.0 \times$ $2.5 \times 2.5 \mathrm{~m}^{3}$ ) for 12 months; at a given time they were in company of another 25-30 individuals that were not the part of the experiment. In aviary, they received unrestricted natural lighting and temperature conditions, although these were not the same, as one would find underneath the bare sky as the aviary was roofed with tin sheets placed about 0.5 meter above the ceiling of the aviary. Birds received natural lights from the three sides (east, north and south). Observations were made fortnightly on body and primary flight feathers, and monthly on the size of testis and ovarian follicle. Three males and one female died before the end of the experiment, and data from them were excluded from the analysis and presentation in the figures.

\section{Series B: Season-dependent variation in sensitivity of the photoperiodic response system}

We investigated whether house sparrow exhibited seasondependent variation in its response to stimulatory long photoperiods. If yes, this might be taken as a physiological reason for the onset and end of growth-regressionregrowth phases of the annual gonadal cycle. In the middle of every month from December 2001 to November 2002, we subjected a group of male and female sparrows
( $\mathrm{n}=5-9$ each) to a long photoperiod (16 hours light:8 hours darkness; 16L:8D) for 17 to 26 weeks. Observations were made on testicular and follicular size at the beginning and the end of the experiment, and at monthly intervals during the experiment.

\section{Series C: Response to varying light-dark (LD) cycles}

This experiment investigated response of male sparrows to day light periods ranging from $2 \mathrm{~h}$ to $22 \mathrm{~h}$ per day, since the species is distributed worldwide. Beginning in third week of January 2004, two experiments were performed employing wild caught adult males that were acclimatized for 4 days in the outdoor aviary before being subjected to an LD cycle.

\section{Experiment I}

Three groups of sparrows $(\mathrm{n}=9-10$ each) were exposed to photoperiods that were close to what they receive during different phase of the annual cycle at this latitude: 9L:15D (close to shortest day length in December), 12L:12D (equinox, in March and September) 15L:9D (close to longest day length in June). The experiment ran for 31 weeks. Observations were made at the beginning and the end of the experiment, and at appropriate intervals (molt: 2 week; testis size - 4 week) during the experiment.

\section{Experiment 2}

Six groups of sparrows ( $n=7-8$ each) were exposed for 17 weeks to photoperiods that contained systematically varying light phase such that it extends to different phases of the daily photosensitivity rhythm (e.g. 2L:22D, 6L:18D, 10L:14D, 14L:10D, 18L:6D and 22L:2D). Observations on testis size were made at the beginning and the end of the experiment, and at intervals of about 4 weeks during the experiment.

Food (seeds of Setaria italica and Oriza sativa) and water were available ad libitum. Male and female birds were always kept separately. In an LD cycle, birds were held in groups of 3 or 4 individuals per cage (size $-45 \times 25 \times 25$ $\mathrm{cm}$ ) within light-tight boxes (size $-138 \times 60 \times 56 \mathrm{~cm}$ ) providing white light produced by fluorescent (Philips) tubes at $~ 500$ lux. Light intensity measurements reflect light illumination at perch level within the cage. Automatic time switches controlled times of light on and light off. Temperature was not strictly regulated, but our photoperiodic boxes are well aerated through inlets and outlets connected to air-circulators, and so temperature inside them does not vary more than $1-2{ }^{\circ} \mathrm{C}$ from the room temperature.

The size of gonads size was recorded by laparotomy as described in our earlier publications [38]. Briefly, a small incision was made between the last two ribs on the left flank, gonads were located within the abdominal cavity 
with the help of a spatula, and the length and width of the left testis or the diameter of largest ovarian follicle was measured. Testis volume (TV) was calculated using the formula $4 / 3 \pi a b^{2}$, where $a$ and $b$ denote half of the long (length) and short (width) axes, respectively. To explain better the induction of a response, we subjectively graded testis size, as described in Kumar et al. [64]: TV $=0.33$ to $<2.35 \mathrm{~mm}^{3}$ - no response; 2.35 to $<9.82 \mathrm{~mm}^{3}$ - initiation of response; 9.82 to $<18.86 \mathrm{~mm}^{3}$ - small response; 18.86 to $<41.9 \mathrm{~mm}^{3}$ - moderate response; $41.9 \mathrm{~mm}^{3}$ and above - full response. Similarly, a regressed ovary with an indistinct follicle was considered having follicular diameter (FD) of $0.3 \mathrm{~mm}$ in order to make data statistically comparable with a stimulated follicle. Molt was studied by scores of feathers of primary flight (wing primaries) and body feathers. As outlined by Boswell [65], we scored primaries in a score of 0-5: 0 - worn or old feather, 1 - missing feather (just dropped), 2 - from a new feather papilla emerging up to attainment of one-third growth, 3 - new feather that has attained two-third growth, 4 - new feather grown, but still growth is incomplete, 5 - new feather fully grown. Thus, each primary could have a maximum score of 5 . Because there are nine primaries on each wing, the maximum score for one wing can be up to $45(9 \times 5=45)$, and for each bird the feather score could total up to 90 (2 $\times 45=90$ ). Similarly, minimum score could be as low as 0 . For recording body molt, we divided the whole bird's body into 11 different regions: 1 - head, 2 - neck, 3 shoulder, 4 - back, 5 - pelvic, 6 - throat, 7 - chest, 8 abdomen, 9 - flank, 10 - shank, and 11 - sub-caudal. Any region could have a score of either 0 (old feathers) or 1 (new feathers emerged), and hence the total body molt score could be in the range of $0-11$, depending on the number of regions had scores of 0 or 1 .

The data are presented as mean and SEs. They were analyzed using one-way analysis of variance (1-way RM ANOVA) with repeated measures, as appropriate, followed by the post hoc Newman-Keuls test, if ANOVA indicated a significance of difference. Two-way ANOVA was used to compare when two factors (e.g. photoperiod and duration) were involved. Two and three groups at one time point were compared using the student's t-test and 1way ANOVA, respectively. Significance was taken at $\mathrm{P}<$ 0.05 .

\section{Acknowledgements}

This study utilized the experimental facility generated from a SERC research grant of the Department of Science and Technology to VK. AKT received a fellowship from this research grant until the year 2002 . We thank all anonymous reviewers for their helpful comments and criticisms, which improved the quality of the manuscript.

\section{References}

I. Wingfield JC, Farner DS: Endocrinology of reproduction in wild species. In Avian Biology Volume IX. Edited by: Farner DS, King JR, Parkes KC. Academic Press, New York; 1993:163-277.

2. Jain N, Kumar V: Changes in food intake, body weight, gonads and plasma concentrations of thyroxine, luteinizing hormone and testosterone in captive buntings exposed to natural daylengths at $29^{\circ} \mathrm{N}$. J Biosci 1995, 20:417-426.

3. Hau M: Timing of breeding in variable environments Tropical birds as model systems. Horm Behav 200I, 40:28I-290.

4. Deviche P, Small T: Photoperiodic control of seasonal reproduction: Neuroendocrine mechanisms and adaptation. In Avian Endocrinology Edited by: Dawson A, Chaturvedi CM. Narosa Publishing House, New Delhi; 200 I: I I3-I 28.

5. Hahn TP, MacDougall-Shackleton SA: Adaptive specialization, conditional plasticity, and phylogenetic history in the reproductive cue response system of birds. Phil Trans Royal Soc in press.

6. Gwinner E, Dittami JP: Photoperiodic responses in temperate zone and equatorial stonechats: A contribution to the problem of photoperiodism in tropical organisms. In The endocrine system and the environment Edited by: Follett BK, Ishii O, Chandola A. Japan Sci Soc Press, Tokyo/Springer Verlag Berlin; 1985:279-294.

7. Gwinner E, Dittami JP: Endogenous reproductive rhythms in a tropical bird. Science 1990, 249:906-908.

8. Murton RK, Westwood NJ: Avian Breeding Cycles Clarendon Press, Oxford; 1977.

9. Chandola A, Singh S, Bhatt D: Photoperiod and circannual rhythms in seasonal reproduction of Indian birds. In Current Trends in Comparative Endocrinology Edited by: Lofts B, Holmes WN. Hong Kong University Press, Hong Kong; 1985:70I-703.

10. Hau M, Wikelski M, Wingfield JC: A neotropical forest bird can measure the slight changes in tropical photoperiod. Proc Royal Soc Lond B 1998, 265:89-95.

II. Styrsky JD, Berthold P, Robinson WD: Endogenous control of migration and calendar effects in an intratropical migrant, the yellow-green vireo. Anim Behav 2004, 67: I I4I-I I 49.

12. Kumar $\mathrm{V}$, Follett $B K$ : The nature of photoperiodic clock in vertebrates. Zool Soc Calcutta (JBS Haldane Comm Vol) 1993:217-227.

13. Gwinner E: Circannual clocks in avian reproduction and migration. Ibis 1996, 138:47-63.

14. Dawson A, McNaughton FJ: Circannual rhythms in starling response of castrated birds to 12 -hr days depends on photoperiodic history. J Biol Rhythms 8:14I-150.

15. Cairns J: The Malayan Great Tit. J Bombay Nat Hist Soc 1956, 53:367-373.

16. Mewaldt LR, King JR: Latitudinal variation of postnuptial molt in pacific coast White-Crowned Sparrows. The Auk 1978, 95:168-174.

17. Pohl $\mathrm{H}$ : Latitudinal and population specific differences in timing of daily and seasonal functions in redpolls (Acanthis flammea). Oecologia 1976, 25:2। I-227.

18. Dark J, Johnston PG, Healy M, Zucker I: Latitude of origin influences photoperiodic control of reproduction of deer mice (Peromyscus maniculatus). Biol Reprod 1983, 28:213-220.

19. Lambrechts MM, Perret P, Blondel J: Adaptive differences in the timing of egg laying between different populations of birds result from variation in photoresponsiveness. Proc $R$ Soc Lond B 1996, 263:19-22.

20. Caro SP, Balthazart J, Thomas DW, Chastel LA, Lambrechts MM: Endocrine correlates of the breeding asynchrony between two Corsican populations of blue tits (Parus caeruleus). Gen Comp Endocrinol 2005, 140:52-60.

21. Moore IT, Perfito N, Wada H, Sperry TS, Wingfield JC: Latitudinal variation in plasma testosterone levels in birds of the genus Zonotrichia. Gen Comp Endocr 2002, 129:13-19.

22. Silverin B, Massa R, Stokkan KA: Photoperiodic adaptation to breeding at different latitudes in great tits. Gen Comp Endocrinol 1993, 90: 14-22.

23. Lambrechts MM, Perret P: A long photoperiod overrides nonphotoperiodic factors in blue tits timing of reproduction. Proc R Soc Lond B 2000, 267:585-588.

24. Hegner RE, Wingfield JC: Annual cycle of gonad size, reproductive hormones, and breeding activity of free-living house sparrows (Passer domesticus (L)) in rural New York. In Graniv- 
orous Birds in the Agricultural Landscape Edited by: Pinowski J, Summerssmith J. Intecol, Warszawa; 1990: I23-135

25. Bentley GE, Perfito N, Ukena K, Tsutsui K: Gonadotropin-inhibitory peptide in song sparrows (Melospiza melodia) in different reproductive conditions, and in house sparrows (Passer domesticus) relative to chicken-gonadotropin-releasing hormone. J Neuroendocrinol 2003, I 5:794-802.

26. Stevenson TJ, MacDougall-Shackleton SA: Season-and age-related variation in neural cGnRH-I and cGnRH-II immunoreactivity in house sparrows (Passer domesticus). Gen Comp Endocrinol 2005, I 43:33-39.

27. Dawson A: Photoperiodic control of testicular regression and moult in male house sparrows, Passer domesticus. Ibis 1991, 133:312-316.

28. Dawson A: Photoperiodic control of the termination of breeding and the induction of moult in house sparrows, Passer domesticus. Ibis 1998, | 40:35-40.

29. Bhardwaj SK, Anushi : Effect of photoperiod length on body mass and testicular growth in the house sparrow (Passer domesticus) and brahminy myna (Sturnus pagodarum). Reprod Nutr Dev 2006, 46:69-76.

30. Trivedi AK, Rani S, Kumar V: Natural daylight restricted to twilights delays the timing of testicular regression but does not affect the timing of the daily activity rhythm of the house sparrow (Passer domesticus). J Circa Rhythms (BMC) 2006, 4:5.

31. Menaker M, Eskin A: Circadian clock in photoperiodic time measurement A test of the Bünning hypothesis. Science 1967, | 57: | |82-I| 85 .

32. Farner DS, Donham RS, Lewis RA, Mattocks PW, Darden TR, Smith JP: The circadian component in the photoperiodic mechanism of the house sparrow, Passer domesticus. Physiol Zool 1977, 50:247-268

33. Trivedi AK, Rani S, Kumar V: Differential responses of the photoperiodic clock in two passerine birds possessing strongly self-sustained circadian system. Chronobiol Int 2005, 22:80 I-806.

34. Murton RK, Westwood NJ: An investigation of photo-refractoriness in the house sparrow by artificial photoperiods. Ibis 1974, I | 6:298-3 I3.

35. Bhardwaj SK, Anushi : The effect of duration and time of food availability on the photoperiodic response in the male house sparrow, Passer domesticus. Reprod Nutr Dev 2004, 44:29-35.

36. Threadgold LT: A study of annual cycle of the housesparrow at various latitudes. Condor 1960, 62:190-201.

37. Farner DS, Donham RS, Matt KS, Mattocks PW, Moore MC, Wingfield JC: The nature of photorefractoriness. In Avian Endocrinology Environmental and Ecological Perspective Edited by: Mikami S, Homma K, Wada M. Japan Scientific Societies Press, Tokyo; 1983:|49-166.

38. Misra M, Rani S, Singh S, Kumar V: Regulation of seasonality in the migratory male blackheaded bunting (Emberiza melanocephala). Reprod Nutr Dev 2004, 44: I-I2.

39. Sarkar A, Ghosh A: Cytological and cytochemical studies on the reproductive cycle of the sub-tropical male house sparrow. La Cellule 1964, 65: I II-126.

40. Daan S, Dijkstra C, Drent R, Meijer T: Food supply and the annual timing of avian reproduction. In Acta XIX Cong Int Ornithol Ottawa Press, Ottawa; 1989:392-407.

41. Nagger RG, Ruegger C, van Noordwijk AJ: Nutrient or energy limitation on egg formation a feeding experiment on great tits. J Anim Ecol 66:495-507.

42. Kumar V, Singh S, Misra M, Malik S: Effects of duration and time of food availability on photoperiodic responses in the migratory male blackheaded bunting (Emberiza melanocephala). J Exp Biol 200I, 204:2843-2848.

43. Farner DS, Lewis RA: Photoperiodism and reproductive cycles in birds. In Photophysiology Volume 6. Edited by: Giese AC. Academic Press, New York; 1971:325-370.

44. Mahmoud IY, Licht P: Seasonal changes in gonadal activity and the effects of stress on reproductive hormones in the common snapping turtle, Chelydra serpentina. Gen Comp Endocr 1997, 107:359-372.

45. Schugardt C, Kirschbaum F: Control of gonadal maturation and regression by experimental variation of environmental factors in the mormyrid fish, Mormyrus rume proboscirostris. Environ Biol Fishes 2004, 70:227-233.
46. Sharp PJ, Massa R, Bottoni L, Lucini V, Lea RW, Dunn IC, Trocchi V: Photoperiodic and endocrine control of seasonal breeding in grey partridge (Perdix perdix). J Zool Lond A 209: I87-200.

47. Singh S, Chandola A: Photoperiodic control of seasonal reproduction in tropical weaver bird. J Exp Zool I98I, 2 I 6:293-298.

48. Kumar V, Kumar BS: The development of photorefractoriness in termination of the breeding season in the tropical brahminy myna Role of photoperiod. Reprod Nutr Dev 1991, $31: 27-36$.

49. Maney DL, Schoech SJ, Sharp PJ, Wingfield JC: Effects of vasoactive intestinal peptide on plasma prolactin in passerines. Gen Comp Endocrinol 1999, I I 3:445-446.

50. Wingfield JC, Hahn TP, Maney DL, Schoech SJ, Wada M, Morton ML: Effects of temeperature on photoperiodically induced reproductive development, circulating plasma luteinizing hormone and thyroid hormones, body mass, fat deposition and molt in mountain white-crowned sparrows, Zonotrichia leucophrys oriantha. Gen Comp Endocrinol 2003, I 3 I: |43-I58.

5I. Follett BK, Maung SL: Rate of testicular maturation, in relation to gonadotrophin and testosterone levels in quail exposed to various artificial photoperiods and to natural daylengths. J Endocrinol 1978, 78:267-280.

52. Moore MC, Schwab H, Farner DS: Biochronometry of testicular regression in white-crowned sparrows (Zonotrichia leucophrys gambelii). J Comp Physiol 1983, I 53:489-494.

53. Rani S, Singh S, Misra M, Malik S, Singh BP, Kumar V: Daily light regulates seasonal responses in the migratory male redheaded bunting (Emberiza bruniceps). J Exp Zool 2005, 303A:54I-550.

54. Dawson A: The effects of daylength and testosterone on the initiation and progress of moult in starlings, Sturnus vulgaris. Ibis 1994, I 36:335-340.

55. Payne RB: Mechanisms and control of molt. In Avian Biology Volume 2. Edited by: King JR, Farner DS. Academic Press, New York; 1972:104-155.

56. Trivedi AK: Seasonal responses of house sparrow (Passer domesticus) Linneaus at $\mathbf{2 7 0 N}$. In PhD Thesis University of Lucknow, Lucknow, India; 2005.

57. Rani S, Kumar V: Time course of sensitivity of thephotoinducible phase to light in the redheaded bunting, Emberiza bruniceps. Biol Rhythm Res 1999, 30:555-562.

58. Thapliyal JP, Tewary PD: Effect of light on the pituitary, gonad and plumage pigmentation in the avadavat, Estrilda amandava, and baya weaver, Ploceus philippinus. Proc Zool Soc London |964, |42:67-7|

59. Chandola A, Thapliyal JP, Pavnaskar I: The effects of thyroidal hormones on the ovarian response to photoperiod in a tropical finch (Ploceus philippinus). Gen Comp Endocr 1974, 24:437-44I.

60. Singh S, Misra M, Rani S, Kumar V: Photoperiodic entrainment and induction of circadian clock regulating seasonal responses in the migratory blackheaded bunting. Chronobiol Int 2002, 19:865-88।.

61. Hinde RA, Steel E: The influence of daylength and male vocalization on the estrogen dependent behaviour of female canaries and budgerigars with discussion of data from other species. In Advances in the Study of Behaviour Edited by: Rosenblatt JS, Hinde RA, Busnel MC. Academic Press, New York; 1978:39-73.

62. Morton ML, Pereyra ME, Baptista LF: Photoperiodically induced ovarian growth in the white crowned sparrow (Zonotrichia leucophrys gambelii) and its augmentation by song. Biochem Physiol A 1985, 80:93-97.

63. Gwinner H, Gwinner E, Dittami JP: Effect of nest boxes on $\mathbf{L H}$, testosterone, Testicular size and the reproductive behaviour of male European starlings in spring. Behaviour 1987, 1 03:68-82.

64. Kumar V, Singh S, Misra M, Malik S, Rani S: Role of melatonin in photoperiodic time measurement in the migratory red headed bunting (Emberiza bruniceps) and the non migratory Indian weaver bird (Ploceus philippinus). I Exp Zool 2002, 292:277-286.

65. Boswell T: The Physiology of migratory fattening in the European quail (Coturnix coturnix). In PhD Thesis University of Bristol, UK; 1991. 